\title{
Implementation of a Project-Based Learning Approach, Case Study of "Mea- surement and Evaluation Techniques in Industrial Engineering" Course
}

\section{Dr. Behin Elahi, Indiana University Purdue University, Fort Wayne}

Dr. Behin Elahi is an Assistant Professor in Industrial Engineering/Industrial Engineering Technology at Purdue University Fort Wayne (Fort Wayne, Indiana). Previously, she was fixed-term instructor at Michigan State University (East Lansing, MI) teaching courses such a manufacturing plan and control, supply chain modeling and management. She got her PhD in Industrial Engineering from the University of Toledo (Toledo, OH) in 2016. She has also a Master degree in industrial Engineering and was a consultant/ project manager of the Business Waste Reduction Assistance Program (BWRAP), a partnership between EPA, University of Toledo and Lucas County in Ohio from 2012-2016. She is a professional and an active member of the Society of Women Engineers, Society of Manufacturing Engineers, Institute for Industrial and System Engineering. 


\title{
Implementation of a Project-Based Learning Approach: Case study of "Measurement and Evaluation Techniques in Industrial Engineering” Course
}

\author{
Behin Elahi \\ Assistant Professor, Ph.D. in Industrial Engineering, Department of Manufacturing and Construction \\ Engineering Technology \\ Purdue University Fort Wayne, 2101 East Coliseum Boulevard, Fort Wayne, Indiana 46805-1499, USA \\ (belahi@purdue.edu)
}

\begin{abstract}
This paper focuses on the advantages of course-based research projects experience in an industrial engineering graduate course. Along with teaching the course materials, students were involved in two research projects. In the first project, they were asked to determine significant factors in a cold drawn process on the ultimate tensile strength of L-605 wire. They applied design of experiment (DOE) technique, identified critical factors and found the best setting for factor level which results in higher yield. In the second project, they were asked to determine a potential optimized structure of 3D-printed material to be used for future space suits. They designed different structures and analyzed the fabric strength versus fabric shape and structure using tensile test. The uniqueness of this project learning paper is the key findings from the study and the associated survey. They demonstrate that the project-based learning approach improves the students' attitudes towards engineering, results in higher-order cognitive learning, boosts their self-efficacy, enhances learning through high retention of the learning material and the subject matter, strengthens team working and communication skills. The results also indicated that the project encouraged group interdependence, active learning, and higher level thinking skills. Students viewed the project as a valuable and interesting experience.
\end{abstract}

Keywords: Project-Based Learning, Design of Experiment, Active Learning

\section{Introduction}

Project-based learning is an instructional approach planned to provide students with the opportunity to develop knowledge and skills through engaging projects set around the challenges 
and problems they may tackle in the real world. It allows the learner to be involved in the analysis of a given project and the search for potential and feasible solutions (Van Den Bogaard and Saunders-Smits, 2007). Such a technique presents opportunities for deeper learning incontext and for the development of important skills tied to college and career readiness (Shaffer et al., 2014; Alves et al., 2012; Fleming 2010). Students' involvement in research projects is attracting more attention in the last decade (Shaffer et al., 2010; Harrison et al., 2011; Gavin 2011). The literature review indicates that project-based learning offer several advantages over traditional courses by enhancing self-efficacy and preparing a unique opportunity for students to put their knowledge into practice (Shaffer et al., 2014; Tamim and Grant 2013). Such experience allows students and instructors to collaboratively bridge the research and classroom and provide research experiences for students relative to traditional individual mentored research. Students who are engaged in research projects report cognitive gains such as a) learning to think and analyze, b) affective gains such as delight, c) psychosocial gains such as belonging to a team, identifying as an effective engineer, and d) behavioral gains such as motivations to pursue graduate education or careers in engineering (Downing et al., 2011; Amamou and ChenitiBelcadhi 2018; O’Sullivan 2013).

This paper analyzes the students' attitude and performance after experiencing a real research projects in "Measurement and Evaluation Techniques in Industrial Engineering” course. Upon completion of the course, students showed increased confidence in using Measurement and Evaluation techniques.

\section{Course Overview and Research Methodology}

In this research, the course of Measurement and Evaluation Techniques in Industrial Engineering (IT 507 graduate level, 3 credit course) was assessed. The course description for the IT507 is: “This course covers applied statistical techniques and design of experiment in solving and analyzing industrial problems. It focuses on measurement and evaluation strategies in the industry."

This study was conducted across two semesters (each semester had 16 weeks, class size of 8 students) for the same course: in the spring of 2017 for a lecture-based classroom course and in the spring 2018 for a mix of lecture-based and problem-based classroom course. The faculty administering the courses in spring 2017 and 2018 was the same. The instructor has taught the course for two semesters before spring 2017 and 2018 (This can have learning effects in the 
instructor as well, which are then transferred into the results of the classroom).

The grade distribution in spring 2017 and 2018 was as follows:

HW and Group assignment 25\%, Midterm Exam 25 \%, Final Exam 30\%, Group Project (presentation and technical report) 20\%. Assessment of project report and oral presentation were conducted using proper rubrics (see Appendix A and Appendix B). In spring 2017, faculty asked students to apply one of measurement techniques on a numerical example, as a course project while in the spring 2018 the faculty decided to engage students in a real research project to apply measurement techniques and solve an issue for industries. In spring 2018, students and the instructor had five on-site visits to tackle the defined project of industries. Every other week, student teams had a group meeting with their instructor and reported their progress in achieving objectives. The research projects provided an opportunity for the students to work in teams, enhance professionalism, and knowledge of contemporary issues - creating 'well rounded' and 'job market ready' engineers upon graduation. The research projects somehow improved students’ understanding of measurement techniques, making over some other approach.

\section{Summary of Conducted Research Projects}

Two projects were defined based on industry's need clearly as follows and students were teamed up to work on them.

First Project: Cold drawing is widely used metal forming process with integral advantages such as closer dimensional tolerances, better surface finish and improved mechanical properties as compared to hot forming processes. A team planned to focus on improving the ultimate tensile strength of L-605 ${ }^{\circledR}$ wire by determining significant factors. L-605 ${ }^{\circledR}$ wire has a number of applications in the aerospace industry and medical industry due to the fact that it maintains moderately high strength even in high temperatures. The cold drawing process has many variables that should be controlled to produce consistent wire properties. Their research focused on evaluation of the effect of speed, tension, and lubrication temperature on the ultimate tensile strength of the cold drawn L-605 ${ }^{\circledR}$ wire via the design of experiment technique. The data analysis verified that speed and tension factors, along with the interaction of speed and temperature, have significant effects on the ultimate tensile strength of the drawn L-605 wire. 


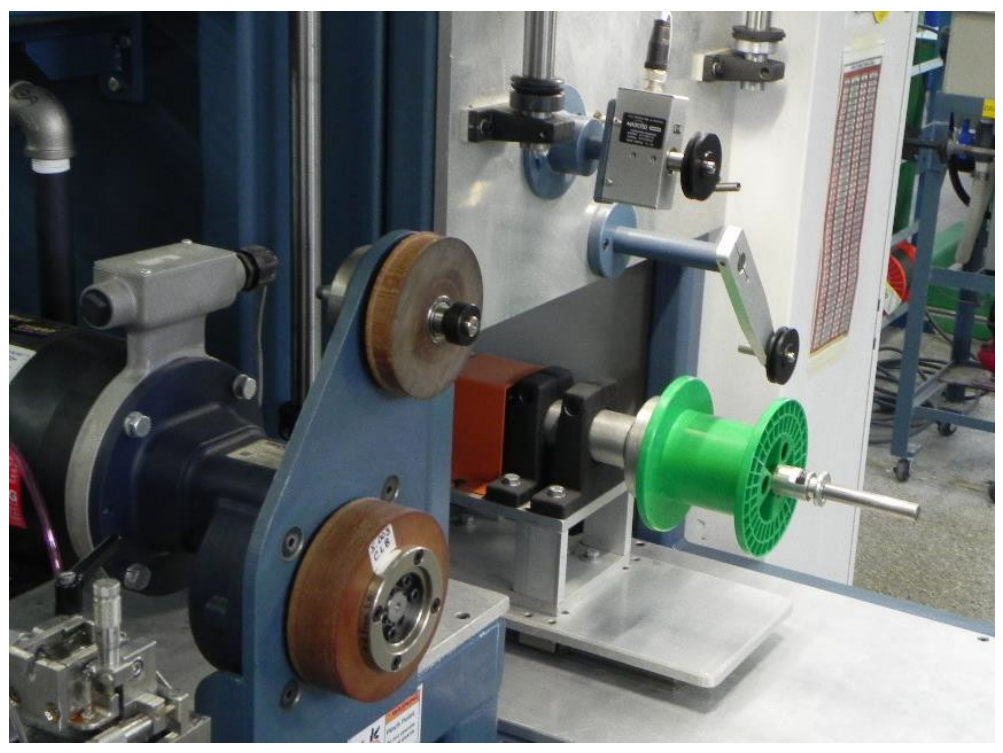

Figure 1. Schematic View of a Small Diameter Wire Drawing Equipment

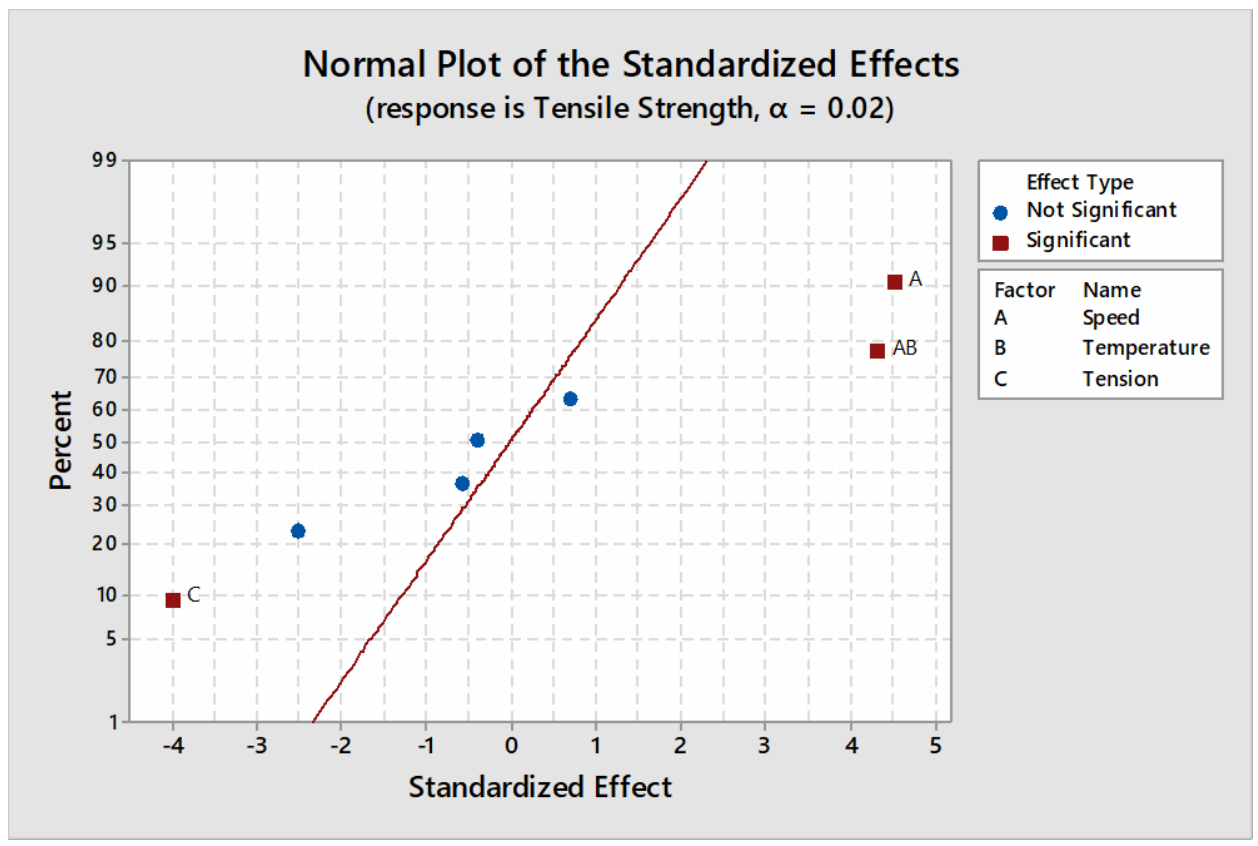

Figure 2. Significant factor effects in Cold drawing process 


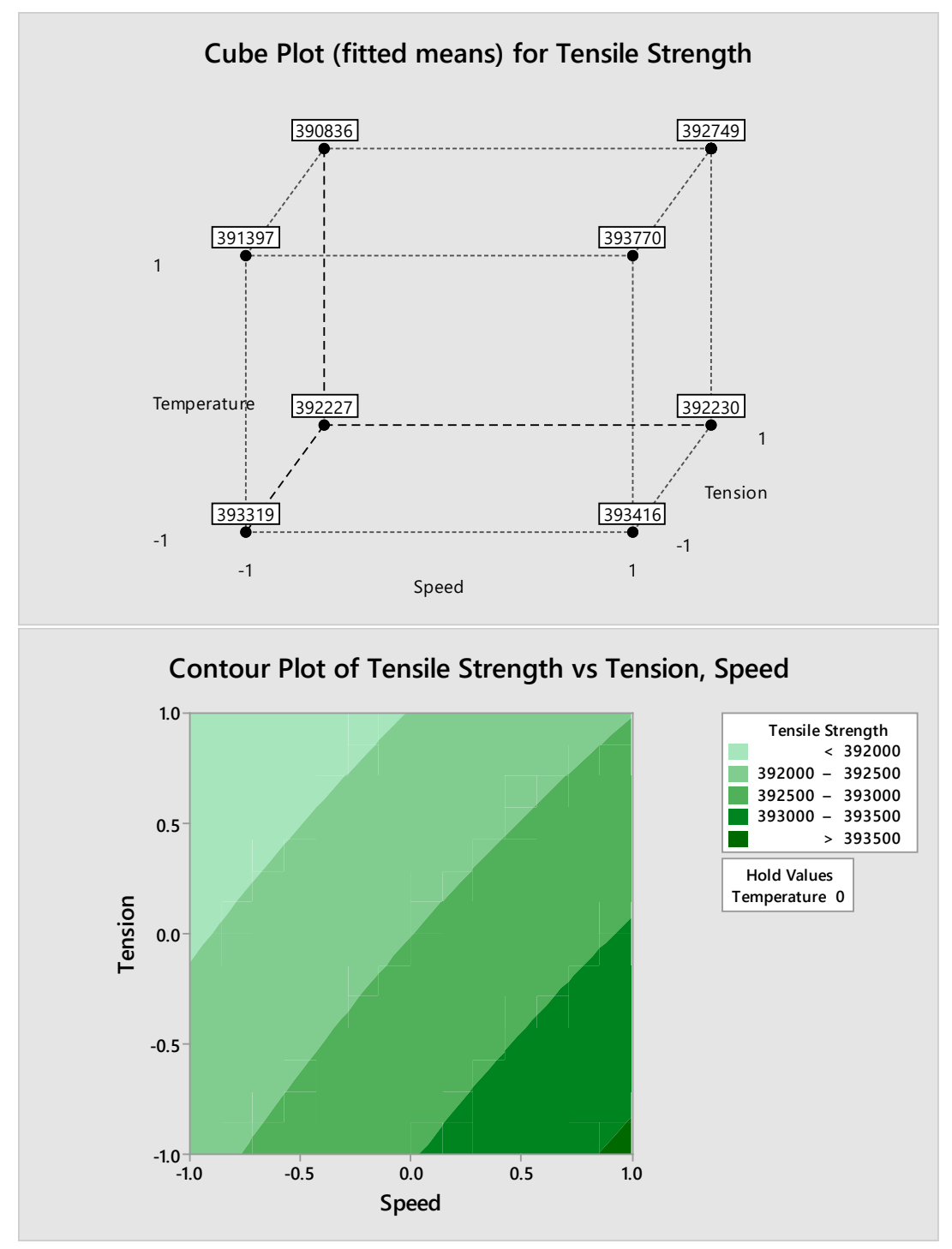

Figure 3. Using Measurement techniques (Contour plot and cubed plot) to analyze data. Second Project: Students focused on an innovative idea to design, make, and test 3D printed fabrics to be used as a flexible skin for future spacecraft, spacesuits, or for deployable antennas.

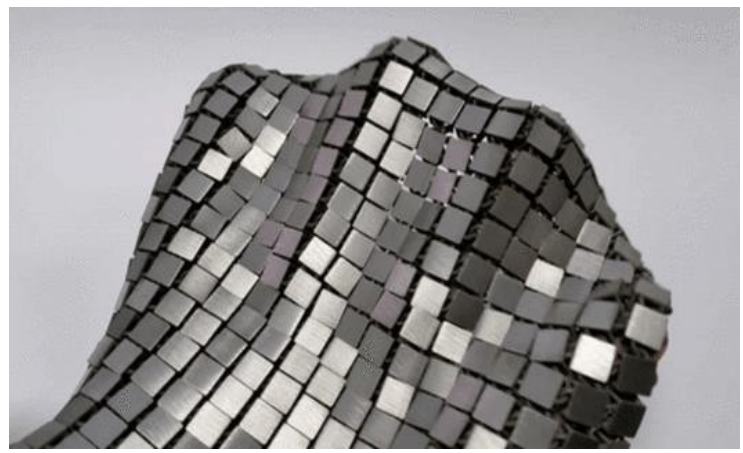

Figure 4. An innovative idea for making 3-D printed fabrics 

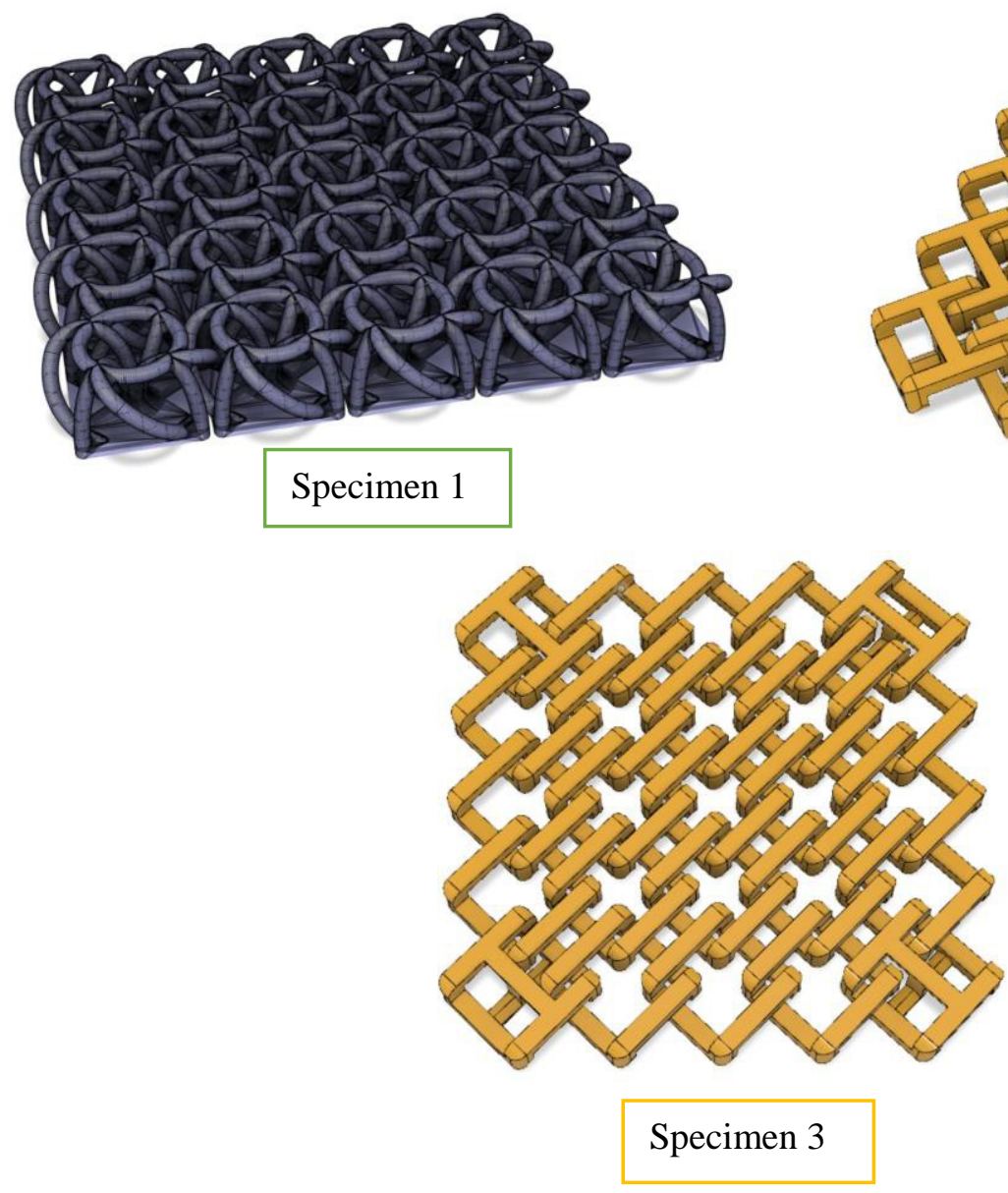

Figure 5. Proposed fabric structure

Specimen 2

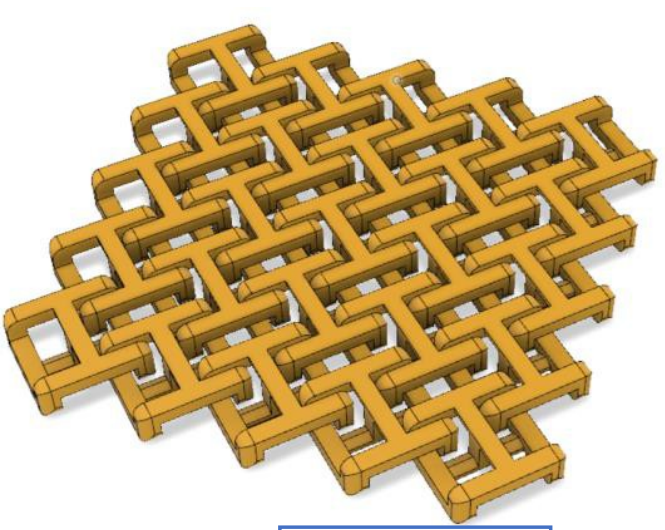

They used Polylactic Acid (PLA), a thermoplastic polymer and printed each structure. They analyzed the Tensile strength of each structure using statistical techniques learned in the related course. 


\section{Test Specimen 1}
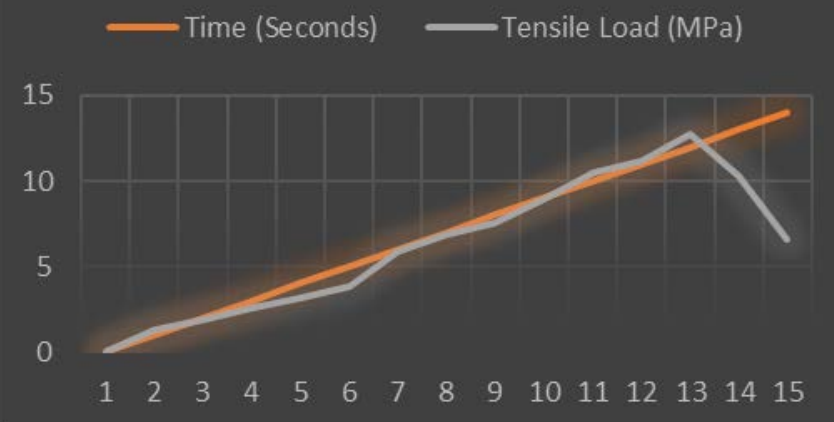

\section{Test Specimen 2}
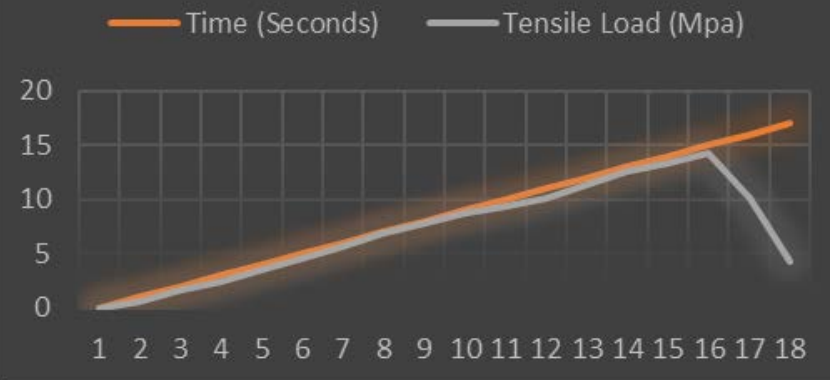

\section{Test Specimen 3}
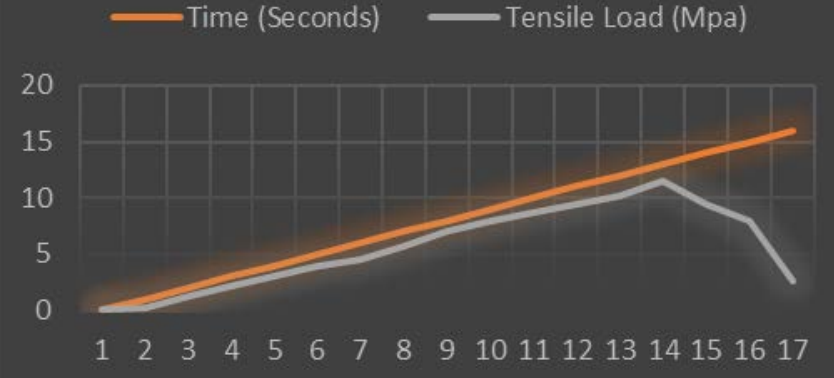

Figure 6. Using Measurement techniques (Tensile test and statistical analysis) to analyze data.

\section{Data Analysis of Learning Outcomes}

The hypotheses of this research defined in a way to evaluate whether "the application of a course-based research project for the "Measurement and Evaluation Techniques in Industrial Engineering” course will:

- Improve the students' attitude towards measurement techniques,

- Enhance the students' understanding of the relevance of subject matter to life and society 
- Improve the student's ability in decision making, problem solving skills, and applying concepts

- Improve the students' self-efficacy (like self-confidence and responsibility)

- Enhance the ease of learning the subject matter for the students

- Enhance team working for the students

- Improve communication skills for the students

- Improve the student's final grades for the course

The hypotheses were tested using the Kolmogorov-Smirnov normality test and t-tests for comparing a) the pre surveys given during the first week of the course in Spring 2017 and Spring 2018, and b) the post surveys given during the last week of the course in Spring 2017 and Spring 2018.

The t-tests were used versus z-tests due to the sample size of 8 for each response, t-tests at the 95\% confidence level were conducted to examine if there were significant differences/improvements from the pre and post assessment survey results in Spring 2017 and 2018 and the results were compared between years.

\section{Null Hypothesis 1:}

$H_{0}$ : There was no difference between the pre and post assessment survey results for each response.

\section{Alternative Hypothesis 1:}

$H_{1}$ : There was a significance difference between the pre and post assessment survey results for each response.

A comparison of the survey results for the two offerings of the course indicated very similar presurvey results that were not statistically different at the $95 \%$ confidence level.

However, the comparison of the spring 2017 classroom versus the spring 2018 classroom post survey indicated statistically significant improvements at the $95 \%$ confidence level.

As displayed in Table 1, the students' mean scores in post survey responses for the spring 2018 classroom have significantly increased. These results indicate that the spring 2018 classroom approach provided better outcomes in terms of student attitudes and self-efficacy. 
Table 1. Post Survey Comparison between Course Offerings (Scale Likert 4 points)

\begin{tabular}{|c|c|c|c|c|c|c|}
\hline & Spring & 2017 & Sprin & 2018 & & Analysis of \\
\hline Question & Mean & $\begin{array}{l}\text { Std. } \\
\text { Dev. }\end{array}$ & Mean & $\begin{array}{l}\text { Std. } \\
\text { Dev. }\end{array}$ & $\begin{array}{c}\mathrm{t} \text { Test } \\
\text { Statistic }\end{array}$ & $\begin{array}{l}\text { Alternative } \\
\text { Hypotheses \#1 } \\
\text { at the } 95 \% \\
\text { Confidence Level }\end{array}$ \\
\hline $\begin{array}{l}\text { 1. The instructional materials, class activities, } \\
\text { labs, assignments, and the research projects were } \\
\text { integrated in a way that made my learning easier }\end{array}$ & 2.83 & 0.84 & 3.89 & 0.73 & $\begin{array}{c}2.6 \\
9\end{array}$ & $\begin{array}{c}\text { P-value }=0.018 \\
\text { HO rejected and } \\
\text { H1 Accepted }\end{array}$ \\
\hline $\begin{array}{l}\text { 2. The instructional materials and research } \\
\text { project emotionally engaged me in learning the } \\
\text { course topics }\end{array}$ & 2.64 & 0.91 & 3.62 & 0.76 & 2.34 & $\begin{array}{c}\text { P-value }=0.036 \\
\text { H0 rejected and } \\
\text { H1 Accepted }\end{array}$ \\
\hline $\begin{array}{l}\text { 3. The instructional materials and research } \\
\text { project involvement increased my self- } \\
\text { confidence }\end{array}$ & 2.84 & 0.79 & 3.82 & 0.74 & 2.56 & $\begin{array}{c}\text { P-value }=0.024 \\
\text { H0 rejected and } \\
\text { H1 Accepted }\end{array}$ \\
\hline $\begin{array}{l}\text { 4. I achieved a sense of accomplishment in } \\
\text { learning by using the instructional materials and } \\
\text { working on a research project with teams }\end{array}$ & 2.86 & 0.74 & 3.69 & 0.72 & 2.27 & $\begin{array}{l}\text { P-value }=0.041 \\
\text { H0 rejected and } \\
\text { H1 Accepted }\end{array}$ \\
\hline $\begin{array}{l}\text { 5. The instructional materials and involvement in } \\
\text { a research project helped me assume a greater } \\
\text { responsibility for personal learning }\end{array}$ & 2.76 & 0.88 & 3.86 & 0.80 & 2.62 & $\begin{array}{l}\text { P-value }=0.021 \\
\text { H0 rejected and } \\
\text { H1 Accepted }\end{array}$ \\
\hline
\end{tabular}

Additionally, if it is assumed that comparing the average GPA of the students in spring 2017 and 2018 can be helpful, an analysis can be conducted on GPAs. The average final grades in the course increased by 6\% (statistically significant at 95\% confidence level, $t$ Test statistic=2.60, pvalue $=0.022 ; \mathrm{n}_{1}$ and $\mathrm{n}_{2}=8$.

\section{Null Hypothesis 2:}

$H_{0}$ : there was no difference between the final grades in Spring 2017 and Spring 2018

\section{Alternative Hypothesis 2:}

$H_{1}$ : there was a significant difference between the final grades in Spring 2017 and Spring 2018

As the p-value is less than the alpha (p-value< 0.05), then the null hypothesis is rejected, and we state the result is statistically significant. 
Table 2. Final Grade Comparison

\begin{tabular}{ccccc}
\hline & \multicolumn{2}{c}{ Midterm Grade } & \multicolumn{2}{c}{ Final Grade } \\
Year & Average & Standard & Standard \\
Spring 2017 & 84.7 & 6.3 & Average & Deviation \\
Spring 2018 & 89.6 & 5.2 & 95.8 & 4.4 \\
\hline
\end{tabular}

\section{Discussion on Validity}

It is important to think about threats to validity. Here, the main focus is on internal and external validity as follows:

\section{a) Threats to Internal Validity}

Extraneous effects (history)

Are participants exposed to events, other than the treatments, whose effects on their behavior could obscure the effects of the independent variable?

Temporal effects (maturation; fatigue)

Do the participants change with the passage of time in ways unrelated to the effects of the independent variable?

Group composition effects (selection)

If different groups are used to compare the effects of treatments, could preexisting differences among the groups obscure the effects of the independent variable?

Interaction of temporal and group composition effects

Could changes in the participants' behavior over time that are related to preexisting differences among groups obscure the effects of the independent variable?

Selective sampling attrition (mortality)

Do participants drop-out of the groups during the study in a systematic or selective way? This could create differences among groups that would obscure the effects of the independent variable.

Statistical regression effects (regression to the mean)

Regression toward the mean: the tendency of extreme (very high or very low) scores to fall closer to the mean on re-testing. Could changes in participants' responses to the measures be caused by this? 


\section{b) Threats to External Validity}

Non-representative sampling

Are the participants in the research study so unrepresentative of those people who need to be understood? This would preclude generalization of the research results from the former to the latter.

\section{Non-representative research context}

Is the context in which the research study was carried out so unrepresentative of contexts where the behavior in question takes place as to preclude generalization of the research results from the former to the latter?

Based on the conducted statistical analysis, the analysis of this paper is valid and can be generalized (There is a potentiality of generalization of this paper's idea regarding similar graduate courses) if it is tested for a larger sample size in different locations and institutions.

\section{Conclusion}

The application and implementation of the course-based research project and real case study to the "Measurement and Evaluation Techniques in Industrial Engineering" course proved to be a value-added addition and will be included in future offerings of the course. The approach enhanced the learning experience by improving the attitudes of the students toward the subject matter. Some limitations of the study include the location and sample size. A larger, more diverse sample would provide broader results.

\section{Reference}

Alves, A.C., Moreira, F., Lima, R., Sousa, R., Dinis-Carvalho, J., Mesquita, D., Fernandes, S. and van Hattum-Janssen, N., 2012, November. Project Based Learning in first year, first semester of Industrial Engineering and Management: some results. In ASME 2012 International Mechanical Engineering Congress and Exposition, pp. 111-120. American Society of Mechanical Engineers.

Amamou, S. and Cheniti-Belcadhi, L. (2018). Tutoring In Project-Based Learning. Procedia Computer Science, 126, pp.176-18.

Downing, K., Ning, F. and Shin, K. (2011). Impact of problem-based learning on student experience and metacognitive development. Multicultural Education \& Technology Journal, 5(1), pp.55-69. 
Fleming, D.S., 2000. A Teacher's Guide to Project-Based Learning. Scarecrow Education, Blue Ridge Summit, PA, pp. 40-47.

Gavin, K., 2011. Case study of a project-based learning course in civil engineering design. European Journal of Engineering Education, 36(6), pp.547-558.

Harrison M., et al. (2011). Classroom-based science research at the introductory level: changes in career choices and attitude. CBE-Life Sci. Educ. 10, 279-286.

O’Sullivan, D., 2003. Online project based learning in innovation management. Education+ Training, 45(2), pp.110-117.

Shaffer, C.D. et al. (2010). The Genomics Education Partnership: successful integration of research into laboratory classes at a diverse group of undergraduate institutions. CBE Life Sci Educ. 9, 55-6.

Shaffer, C.D. et al. (2014). A Course-Based Research Experience: How Benefits Change with Increased Investment in Instructional Time. CBE-Life Sci. Educ. 13, 111-130.

Tamim, S.R. and Grant, M.M. (2013). Definitions and uses: Case study of teachers implementing project-based learning. Interdisciplinary Journal of Problem-Based Learning, 7(2), pp.3.

Van Den Bogaard, M.E. and Saunders-Smits, G.N., 2007, October. Peer \& self-evaluations as means to improve the assessment of project based learning. In Frontiers In Education Conference-Global Engineering: Knowledge Without Borders, Opportunities Without Passports, 2007. FIE'07. 37th Annual (pp. S1G-12). IEEE. 


\section{Appendix A}

\section{Assessment of Project Report}

Max Score $=120$

Reviewer’s Initial:

Date:

Name of Student:

Title:

\section{Writing Communication}

(Decimal scores are allowed)

\begin{tabular}{|c|c|c|c|c|c|c|c|c|}
\hline & Weight & $\begin{array}{l}\text { Total } \\
\text { Score }\end{array}$ & Score & A & B & C & $\mathrm{D}$ & $\mathrm{F}$ \\
\hline Criteria & & & & 4 & 3 & 2 & 1 & 0 \\
\hline $\begin{array}{l}\text { Report writing is } \\
\text { clear and concise. }\end{array}$ & 2 & & & $\begin{array}{l}\text { Report is to the } \\
\text { point, clear, and } \\
\text { concise. } \\
\text { Coverage is } \\
\text { good. }\end{array}$ & $\begin{array}{l}\text { Report sometimes } \\
\text { deviates from the } \\
\text { subject. } \\
\text { Coverage is } \\
\text { adequate. }\end{array}$ & $\begin{array}{l}\text { Report } \\
\text { deviates from } \\
\text { the subject. } \\
\text { Coverage is } \\
\text { not adequate. }\end{array}$ & $\begin{array}{l}\text { Report is } \\
\text { vague. } \\
\text { Coverage is } \\
\text { poor. }\end{array}$ & $\begin{array}{l}\text { Report not } \\
\text { written }\end{array}$ \\
\hline $\begin{array}{l}\text { Report is well } \\
\text { organized and easy } \\
\text { to follow. }\end{array}$ & 2 & & & $\begin{array}{l}\text { Good headings. } \\
\text { Appropriate } \\
\text { paragraphs. } \\
\text { Followed } \\
\text { formatting } \\
\text { instructions. }\end{array}$ & $\begin{array}{l}\text { Appropriate } \\
\text { headings. } \\
\text { Long paragraphs. } \\
\text { Missed some } \\
\text { instructions. }\end{array}$ & $\begin{array}{l}\text { Few headings. } \\
\text { Long } \\
\text { paragraphs. } \\
\text { Missed many } \\
\text { instructions. }\end{array}$ & $\begin{array}{l}\text { No headings. } \\
\text { Long } \\
\text { paragraph. } \\
\text { Missed all } \\
\text { instructions. }\end{array}$ & $\begin{array}{l}\text { Report not } \\
\text { written }\end{array}$ \\
\hline $\begin{array}{l}\text { Report is written in } \\
\text { professional } \\
\text { language and style. }\end{array}$ & 3 & & & $\begin{array}{l}\text { Proper words } \\
\text { used. } \\
\text { Written in third } \\
\text { person. } \\
\text { Good } \\
\text { Exceptional. }\end{array}$ & $\begin{array}{l}\text { Some improper } \\
\text { word used. } \\
\text { Written in third } \\
\text { person. } \\
\text { Good. }\end{array}$ & $\begin{array}{l}\text { Frequently } \\
\text { improper } \\
\text { words used. } \\
\text { Written in first } \\
\text { person. } \\
\text { Fair. }\end{array}$ & $\begin{array}{l}\text { Frequent } \\
\text { improper } \\
\text { words used. } \\
\text { Written in first } \\
\text { person. } \\
\text { Needs } \\
\text { improvement. }\end{array}$ & $\begin{array}{l}\text { Report not } \\
\text { written }\end{array}$ \\
\hline $\begin{array}{l}\text { Report free of } \\
\text { typographical errors. }\end{array}$ & 1 & & & 0 errors. & $\begin{array}{l}1 \text { to } 3 \text { minor } \\
\text { errors. }\end{array}$ & $\begin{array}{l}4 \text { to } 5 \text { minor } \\
\text { errors. }\end{array}$ & $\begin{array}{l}6 \text { to } 7 \text { minor } \\
\text { errors. }\end{array}$ & $\begin{array}{l}8 \text { or more } \\
\text { errors }\end{array}$ \\
\hline $\begin{array}{l}\text { Use of appropriate } \\
\text { technical literature. }\end{array}$ & 2 & & & $\begin{array}{l}\text { Appropriate and } \\
\text { current technical } \\
\text { literature used. }\end{array}$ & $\begin{array}{l}\text { Appropriate but } \\
\text { older technical } \\
\text { literature used. }\end{array}$ & $\begin{array}{l}\text { Appropriate } \\
\text { but outdated } \\
\text { technical } \\
\text { literature used. }\end{array}$ & $\begin{array}{l}\text { Inappropriate } \\
\text { technical } \\
\text { literature used. }\end{array}$ & $\begin{array}{l}\text { Not given } \\
\text { in the } \\
\text { report }\end{array}$ \\
\hline \multicolumn{2}{|l|}{$\begin{array}{l}\text { Outcome } g 1 \text { score } \\
\text { Max }=40\end{array}$} & & \multicolumn{6}{|c|}{ Comments: } \\
\hline
\end{tabular}


Professional Development

\begin{tabular}{|c|c|c|c|c|c|c|c|c|}
\hline \multirow{2}{*}{$\begin{array}{l}\text { Performance } \\
\text { Criteria }\end{array}$} & \multirow[t]{2}{*}{ Wt. } & \multirow{2}{*}{$\begin{array}{l}\text { Total } \\
\text { Score }\end{array}$} & \multirow[t]{2}{*}{ Score } & A & B & C & D & $\mathrm{F}$ \\
\hline & & & & 4 & 3 & 2 & 1 & 0 \\
\hline $\begin{array}{l}\text { Use external sources } \\
\text { in course/project } \\
\text { work }\end{array}$ & 5 & & & $\begin{array}{l}\text { Reliable external } \\
\text { sources used. }\end{array}$ & $\begin{array}{l}\text { External sources } \\
\text { used. }\end{array}$ & $\begin{array}{l}\text { Some external } \\
\text { sources used. }\end{array}$ & $\begin{array}{l}\text { Internal } \\
\text { sources } \\
\text { only used. }\end{array}$ & $\begin{array}{l}\text { No sources } \\
\text { used at all. }\end{array}$ \\
\hline $\begin{array}{l}\text { Outcome } h \text { score } \\
\text { Max }=20\end{array}$ & & & \multicolumn{6}{|c|}{ Comments: } \\
\hline
\end{tabular}

\section{References}

\begin{tabular}{|c|c|c|c|c|c|c|c|c|}
\hline & Wt. & Total & Score & $\mathrm{A}$ & B & $\mathrm{C}$ & $\mathrm{D}$ & $\mathrm{F}$ \\
\hline Criteria & & & & 4 & 3 & 2 & 1 & 0 \\
\hline $\begin{array}{l}\text { All references cited } \\
\text { in the written work }\end{array}$ & 5 & & & $\begin{array}{l}\text { All references } \\
\text { cited clearly in the } \\
\text { text. }\end{array}$ & $\begin{array}{l}\text { Most references } \\
\text { cited in the text. }\end{array}$ & $\begin{array}{l}\text { Some } \\
\text { references } \\
\text { cited in the } \\
\text { text. }\end{array}$ & $\begin{array}{l}\text { Few } \\
\text { references } \\
\text { cited in the } \\
\text { text. }\end{array}$ & None cited. \\
\hline $\begin{array}{l}\text { Outcome } i_{1} \text { score } \\
\operatorname{Max}=20\end{array}$ & & & Comm & & & & & \\
\hline
\end{tabular}

\section{Creativity in Design}

\begin{tabular}{|c|c|c|c|c|c|c|c|c|}
\hline Performance & Wt. & Total & Score & $\bar{A}$ & B & $\mathrm{C}$ & $\mathrm{D}$ & $\mathrm{F}$ \\
\hline Criteria & & & & 4 & 3 & 2 & 1 & 0 \\
\hline $\begin{array}{l}\text { Select a well-defined } \\
\text { problem for project. }\end{array}$ & 4 & & & $\begin{array}{l}\text { Project description } \\
\text { is clearly defined } \\
\text { and explained. }\end{array}$ & $\begin{array}{l}\text { Project } \\
\text { description is } \\
\text { clear but needs } \\
\text { explanation. }\end{array}$ & $\begin{array}{l}\text { Project } \\
\text { description } \\
\text { not clear and } \\
\text { needs } \\
\text { explanation. }\end{array}$ & $\begin{array}{l}\text { Project } \\
\text { description } \\
\text { is not clear } \\
\text { at all. }\end{array}$ & $\begin{array}{l}\text { Project } \\
\text { not done. }\end{array}$ \\
\hline $\begin{array}{l}\text { Design using proper } \\
\text { knowledge and skills. }\end{array}$ & 4 & & & $\begin{array}{l}\text { All knowledge and } \\
\text { skills were used. }\end{array}$ & $\begin{array}{l}\text { Some relevant } \\
\text { knowledge and } \\
\text { skills were not } \\
\text { used. }\end{array}$ & $\begin{array}{l}\text { Important } \\
\text { knowledge } \\
\text { and skills } \\
\text { were not used. }\end{array}$ & $\begin{array}{l}\text { Irrelevant } \\
\text { knowledge } \\
\text { and skills } \\
\text { were used. }\end{array}$ & $\begin{array}{l}\text { Project } \\
\text { not done. }\end{array}$ \\
\hline $\begin{array}{l}\text { Design creatively and } \\
\text { accurately. }\end{array}$ & 2 & & & $\begin{array}{l}\text { Very creative in } \\
\text { design. }\end{array}$ & $\begin{array}{l}\text { Reasonable } \\
\text { creativity is } \\
\text { shown in the } \\
\text { design. }\end{array}$ & $\begin{array}{l}\text { Little } \\
\text { creativity is } \\
\text { shown in the } \\
\text { design. }\end{array}$ & $\begin{array}{l}\text { Textbook } \\
\text { application } \\
\text { in the } \\
\text { project } \\
\text { design. }\end{array}$ & $\begin{array}{l}\text { Project } \\
\text { not done. }\end{array}$ \\
\hline \multicolumn{2}{|l|}{$\begin{array}{l}\text { Outcome } d \text { score } \\
M a x=40\end{array}$} & & \multicolumn{6}{|c|}{ Comments: } \\
\hline
\end{tabular}

\begin{tabular}{|l|l|l|}
\hline Overall Project & Overall Comments: \\
Score & & \\
Max $=120$ & & \\
\hline
\end{tabular}




\section{Appendix B}

\section{Assessment of Student Presentation}

Max Score $=40$

Name of Student:

Date:

Start time:

Finish time:

(Decimal scores are allowed)

\begin{tabular}{|c|c|c|c|c|c|c|c|c|}
\hline \multirow{2}{*}{$\begin{array}{l}\text { Performance } \\
\text { Criteria }\end{array}$} & \multirow[t]{2}{*}{ Weight } & \multirow{2}{*}{$\begin{array}{l}\text { Total } \\
\text { Score }\end{array}$} & \multirow[t]{2}{*}{ Score } & $\mathrm{A}$ & B & $\mathrm{C}$ & $\mathrm{D}$ & $\mathrm{F}$ \\
\hline & & & & 4 & 3 & 2 & 1 & 0 \\
\hline $\begin{array}{l}\text { The presentation } \\
\text { includes } \\
\text { introduction, body, } \\
\text { conclusions, and } \\
\text { references. }\end{array}$ & 2 & & & $\begin{array}{l}\text { They are given } \\
\text { very clearly. } \\
\text { Time spent on } \\
\text { each was } \\
\text { adequate. }\end{array}$ & $\begin{array}{l}\text { They are fairly } \\
\text { clear. } \\
\text { Time spent on } \\
\text { one was short. }\end{array}$ & $\begin{array}{l}\text { They are just clear. } \\
\text { Time spent on two or more was } \\
\text { short. }\end{array}$ & $\begin{array}{l}\text { They are } \\
\text { barely clear. } \\
\text { Time spent } \\
\text { on all three } \\
\text { was short. }\end{array}$ & $\begin{array}{l}\text { Not } \\
\text { done. }\end{array}$ \\
\hline $\begin{array}{l}\text { The student } \\
\text { communicates } \\
\text { clearly. }\end{array}$ & 3 & & & $\begin{array}{l}\text { Communicates } \\
\text { very clearly. } \\
\text { Eye contact is } \\
\text { good. }\end{array}$ & $\begin{array}{l}\text { Clear but some } \\
\text { "ums". } \\
\text { Eye contact is } \\
\text { ok. }\end{array}$ & $\begin{array}{l}\text { Sometimes hard to hear. } \\
\text { Read from script. }\end{array}$ & $\begin{array}{l}\text { Mumbled } \\
\text { most of the } \\
\text { time. } \\
\text { Often had } \\
\text { back to } \\
\text { audience. }\end{array}$ & $\begin{array}{l}\text { Not } \\
\text { done. }\end{array}$ \\
\hline $\begin{array}{l}\text { The student has } \\
\text { well-prepared } \\
\text { audiovisual } \\
\text { materials. }\end{array}$ & 2 & & & $\begin{array}{l}\text { Slides well } \\
\text { prepared. } \\
\text { All slides were } \\
\text { clear. }\end{array}$ & $\begin{array}{l}\text { Slides well } \\
\text { prepared. } \\
\text { Few slides not } \\
\text { clear. }\end{array}$ & $\begin{array}{l}\text { Slides were ok. } \\
\text { Most slides not clear. }\end{array}$ & $\begin{array}{l}\text { Poor slides. } \\
\text { Hand drawn } \\
\text { sketches. }\end{array}$ & $\begin{array}{l}\text { Not } \\
\text { done. }\end{array}$ \\
\hline $\begin{array}{l}\text { The student } \\
\text { responds } \\
\text { effectively to } \\
\text { questions \& } \\
\text { comments. }\end{array}$ & 2 & & & $\begin{array}{l}\text { Most questions } \\
\text { answered } \\
\text { correctly and } \\
\text { confidently. }\end{array}$ & $\begin{array}{l}\text { Most questions } \\
\text { answered, but } \\
\text { lacked } \\
\text { confidence. }\end{array}$ & $\begin{array}{l}\text { Answers were weak or not in } \\
\text { sync with questions. }\end{array}$ & $\begin{array}{l}\text { Could not } \\
\text { answer } \\
\text { questions. } \\
\text { No time for } \\
\text { Q\&A }\end{array}$ & $\begin{array}{l}\text { Not } \\
\text { done. }\end{array}$ \\
\hline $\begin{array}{l}\text { The student } \\
\text { dresses } \\
\text { appropriately. }\end{array}$ & 1 & & & $\begin{array}{l}\text { The dress was } \\
\text { appropriate for } \\
\text { technical } \\
\text { presentation. } \\
\text { Exuded } \\
\text { confidence. }\end{array}$ & $\begin{array}{l}\text { The dress was } \\
\text { acceptable for } \\
\text { technical } \\
\text { presentation. } \\
\text { Confidence was } \\
\text { adequate. }\end{array}$ & $\begin{array}{l}\text { The dress was casual. } \\
\text { Confidence was weak. }\end{array}$ & $\begin{array}{l}\text { Dress was } \\
\text { very casual. } \\
\text { Did not take } \\
\text { the subject } \\
\text { seriously. }\end{array}$ & $\begin{array}{l}\text { Not } \\
\text { done. }\end{array}$ \\
\hline Overall Score & & & $\underline{\text { Comr }}$ & nts: & & & & \\
\hline
\end{tabular}




\section{Appendix C}

\section{Post-Survey}

\begin{tabular}{|l|c|c|c|c|}
\hline $\begin{array}{l}\text { Please indicate how strongly you agree or } \\
\text { disagree with the following statements: }\end{array}$ & $\begin{array}{l}\text { Strongly } \\
\text { Disagree }\end{array}$ & Disagree & Agree & $\begin{array}{l}\text { Strongly } \\
\text { agree }\end{array}$ \\
\hline $\begin{array}{l}\text { The instructional materials, class activities, labs, } \\
\text { assignments, and the research projects were } \\
\text { integrated in a way that made my learning easier }\end{array}$ & $\mathrm{O}$ & $\mathrm{O}$ & $\mathrm{O}$ & $\mathrm{O}$ \\
\hline $\begin{array}{l}\text { The instructional materials and research project } \\
\text { emotionally engaged me in learning the course } \\
\text { topics }\end{array}$ & $\mathrm{O}$ & $\mathrm{O}$ & $\mathrm{O}$ & $\mathrm{O}$ \\
\hline $\begin{array}{l}\text { The instructional materials and research project } \\
\text { involvement increased my self-confidence }\end{array}$ & $\mathrm{O}$ & $\mathrm{O}$ & $\mathrm{O}$ & $\mathrm{O}$ \\
\hline $\begin{array}{l}\text { I achieved a sense of accomplishment in learning } \\
\text { by using the instructional materials and working on } \\
\text { a research project with teams }\end{array}$ & $\mathrm{O}$ & $\mathrm{O}$ & $\mathrm{O}$ & $\mathrm{O}$ \\
\hline $\begin{array}{l}\text { I achieved a sense of accomplishment in learning } \\
\text { by using the instructional materials and working on } \\
\text { a research project with teams }\end{array}$ & $\mathrm{O}$ & $\mathrm{O}$ & $\mathrm{O}$ & $\mathrm{O}$ \\
\hline
\end{tabular}

